\title{
Fungsionalisasi Prinsip Dominus Litis Dalam Penegakan Hukum Pidana Di Indonesia
}

\author{
Tiar Adi Riyanto \\ Magister Hukum Fakultas Hukum Universitas Islam Indonesia Yogyakarta Indonesia \\ Jln. Cik Di Tiro No. 1 Yogyakarta Indonesia \\ tiaradiriyanto@gmail.com
}

\begin{abstract}
This study aims to determine the functionalization of the principle of dominus litis in criminal law enforcement in Indonesia. This is a normative legal research that uses a statutory and conceptual approaches. The results of this study concluded that the principle of dominus litis is functionalized in the regulation of the authority to stop the prosecution of the prosecutor's office, as regulated in Article 140 paragraph (2) of the Criminal Procedure Code. In addition, restorative justice is one of the efforts that the Prosecutor's Office can do in functionalizing the dominus litis principle, for example, the mediation process (penal mediation) as regulated in Law Number 11 of 2012 on the Juvenile Criminal Justice System.
\end{abstract}

Key Words: Criminal law enforcement; dominus litis; prosecutor's office; restorative justicee

\begin{abstract}
Abstrak
Penelitian ini bertujuan untuk mengetahui fungsionalisasi prinsip dominus litis dalam penegakan hukum pidana di Indonesia. Penelitian ini merupakan penelitian hukum normatif yang menggunakan pendekatan perundang-undangan dan pendekatan konseptual. Hasil penelitian ini menyimpulkan bahwa prinsip dominus litis terfungsionalisasi dalam pengaturan kewenangan untuk menghentikan penuntutan yang dimiliki oleh kejaksaan, sebagaimana diatur dalam Pasal 140 ayat (2) KUHAP. Selain itu, keadilan restoratif merupakan salah satu upaya yang dapat dilakukan Kejaksaan dalam memfungsionalisasikan prinsip dominus litis, contohnya yaitu proses mediasi (mediasi penal) yang diatur dalam Undang-Undang Nomor 11 Tahun 2012 tentang Sistem Peradilan Pidana Anak.
\end{abstract}

Kata-kata Kunci: Dominus litis; keadilan restorati; kejaksaan; penegakan hukum pidana 


\section{Pendahuluan}

Indonesia sebagai negara hukum tentunya sangat menjunjung tinggi hukum yang berlaku dan diposisikan sebagai alat untuk mengatur kehidupan berbangsa dan bernegara, sehingga penegakkan hukum menempati posisi yang sangat sentral di Indonesia, dimana negara menempatkan hukum dalam fungsinya sebagai alat pengatur bagi kehidupan bermasyarakat baik hubungannya dengan penguasa maupun antara masyarakat itu sendiri. Hukum dan masyarakat seperti dua sisi mata uang yang tidak bisa dipisahkan satu sama lain. Berlakunya hukum didalam suatu tatanan sosial yang disebut masyarakat, oleh bangsa Romawi disebut sebagai ubi societas ibi ius yang menggambarkan betapa eratnya hubungan antara hukum dan masyarakat. ${ }^{1}$

Hukum berguna untuk melindungi masyarakat agar terhindar dari penyelewengan hak dan kewajiban, karena ketiadaan aturan atau hukum bisa mengakibatkan chaos atau kekacauan. Dilihat dari pandangan masyarakat secara universal, perkembangan kejahatan adalah salah satu ancaman utama yang menjadi fokus perhatian untuk diantisipasi. Upaya dalam penanggulangan kejahatan ini menjadi tanggung jawab bersama komponen bangsa, baik pemerintah maupun masyarakat. Dalam hal ini negara melalui organ-organnya telah membentuk suatu aparat penegak hukum yang berwenang melakukan tugas dan tanggung jawab terkait dengan penegakan hukum. Aparat penegak hukum dianggap memiliki tanggung jawab terdepan dalam penanggulangan kejahatan dan penegakan hukum. Dengan demikian apabila setiap kejahatan teratasi maka masyarakat sebagai hasilnya akan puas dimana keadilan telah ditegakkan dan yang bersalah telah dijatuhi sesuai dengan hukuman yang berlaku.

Semakin maju sebuah peradaban maka hal ini akan berbanding lurus dengan perkembangan berpikir masyarakat dimana dalam hal ini kejahatan juga akan berkembang seiring perkembangan zaman tersebut. Hal ini juga berakibat pada berkembangnya kejahatan baik terkait modus, kualitas ataupun kuantitasnya selalu lebih depan di bandingkan aparat penegak hukum. Kejahatan lebih mengancam dibanding sebelumnya dan menjadi konsumsi publik, yaitu menjadi bagian dari percakapan masyarakat sehari-hari dan selalu memunculkan reaksi kuat di masyarakat. ${ }^{2}$

Kejahatan membawa kerugian yang besar bagi masyarakat. Perkembangan kejahatan juga berdampak pada sikap masyarakat. Ketika terjadi peningkatan atau gelombang kejahatan (crime waves), orang mengubah tingkah laku mereka

\footnotetext{
${ }^{1}$ Mochtar Kusumaatmadja, Konsep-Konsep Dalam Pembangunan, PT. Alumni, Bandung, 2006, hlm. 3

2 Jhon E. Conklin, The Impact Of Crime, McMillan Publishing Co, New York, 1975, hlm. 2.
} 
guna melindungi diri maupun keluarga dan harta bendanya dari serangan para penjahat, seolah-olah seperti binatang yang tengah diburu. Ongkos kerugian yang dikeluarkan akibat ketakutan pada kejahatan tersebut tidak jarang justru lebih mahal dari kejahatan itu sendiri. Terkait hal ini, ongkos langsung (direct cost) yaitu pada kejahatannya sendiri dan ongkos tidak langsung (indirect cost) yaitu merujuk pada reaksi terhadap tingkah laku kriminal. ${ }^{3}$ Artinya, kejahatan juga menimbulkan kerugian tak langsung yaitu biaya yang dikeluarkan negara dalam menyelenggarakan sistem peradilan pidana yang harus memproses tersangka atau terdakwa hingga berstatus sebagai terpidana, yang melingkupi biaya untuk lembaga kepolisian, kejaksaan, pengadilan maupun lembaga pemasyarakatan.

Penegakan hukum dalam pengertian makro meliputi seluruh aspek kehidupan masyarakat, berbangsa dan bernegara, sedangkan dalam pengertian mikro penegakan hukum terbatas dalam proses litigasi di pengadilan, dalam perkara pidana termasuk proses penyelidikan, penyidikan, penuntutan (pemeriksaan di depan persidangan) hingga pelaksanaan putusan pengadilan yang telah mempunyai kekuatan hukum tetap. ${ }^{4}$ Dalam hal terjadinya suatu peristiwa yang patut diduga merupakan tindak pidana maka wajib segera dilakukan tindakan yang diperlukan guna menyelesaikannya, dengan melakukan penyelidikan, Penyidikan, penuntutan dan pemeriksaan di pengadilan. ${ }^{5}$

Dua komponen yang menjadi pintu gerbang proses penegakan hukum dalam sistem peradilan pidana adalah polisi dan jaksa. Polisi sebagai penyidik dan jaksa sebagai penuntut umum. Dua institusi inilah yang menentukan nasib seorang warga negara menjadi tersangka kemudian terdakwa lalu terpidana. Hubungan antara Jaksa dan Polisi adalah hubungan yang kompleks. Masyarakat melihat bahwa Polisi dan Jaksa merupakan partner yang tak terpisahkan namun dalam prakteknya secara internal sering terjadi konflik antara kepolisian dan kejaksaan dalam melaksanakan tugasnya masing-masing.

Koordinasi antar lembaga negara khususnya penegak hukum masih menjadi pekerjaan rumah terbesar pemerintahan sekarang dalam hal reformasi hukum. Terkait hal ini, hubungan antara Penyidik dan Penuntut Umum sering diwarnai perselisihan karena Penyidik merasa mempunyai kedudukan yang setara dengan Penuntut Umum. Di sisi lain, Penuntut Umum mempunyai posisi yang cukup sentral sebagai salah satu gerbang proses peradilan pidana dimana berdasarkan tugas dan wewenangnya Jaksa Penuntut Umum setelah mempelajari dan meneliti suatu berkas perkara yang diajukan oleh Penyidik. Jaksa Penuntut Umum

\footnotetext{
${ }^{3}$ Conklin, Op. Cit., hlm. 3.

${ }^{4}$ Marwan Effendy, "Deskresi Dalam Penegakan Hukum Tindak Pidana Korupsi", Makalah disampaikan pada Seminar Nasional yang diselenggarakan oleh Universitas Brawijaya Malang, Malang, 11 Juni 2012, hlm. 2-3.

${ }^{5}$ Erni Widhayanti, Hak-Hak Tersangka/Terdakwa di dalam KUHAP, Liberty, Yogyakarta, 1996, hlm. 48
} 
selanjutnya menyimpulkan bahwa apabila alat bukti dalam suatu perkara telah terpenuhi dan sesuai dengan peraturan didalam KUHAP, akan mengajukan penuntutan ke Pengadilan Negeri sehingga Penuntut Umum dipandang mempunyai posisi yang sentral dalam pembuktian suatu perkara di persidangan.

Salah satu prinsip yang dikenal dalam tahap penuntutan yaitu dominus litis, yang artinya 'jaksa' atau penguasa perkara sehingga dalam proses peradilan pidana, jaksalah yang berwenang apakah suatu perkara dapat dilakukan penuntutan ke pengadilan atau tidak. ${ }^{6}$ Menurut Surachman, di beberapa negara seperti Jepang, Belanda dan Perancis, wewenang penuntutan adalah monopoli Jaksa. Di Indonesia, prinsip ini menjadi dasar kewenangan jaksa penuntut umum untuk melakukan penuntutan.7 Prinsip Dominus Litis telah diakui secara universal dan tercermin di dalam Pasal 2 Undang-Undang Nomor 16 Tahun 2004 tentang Kejaksaan Republik Indonesia yang menyebutkan bahwa Kejaksaan merupakan lembaga pemerintahan yang melaksanakan kekuasaan negara di bidang penuntutan serta kewenangan lain berdasarkan undang-undang, yang dilaksanakan secara independen. ${ }^{8}$

Kitab Undang-Undang Hukum Acara Pidana (KUHAP) tidak menerapkan prinsip dominus litis atau kewenangan mutlak yang diberikan kepada Instansi Kejaksaan Republik Indonesia dalam proses penanganan perkara pidana. Hal tersebut mengakibatkan posisi jaksa selaku Penuntut Umum sebagai bagian dari Instansi Kejaksaan dipandang kurang karena hanya memeriksa secara formal berkas perkara saja, tidak mengetahui proses dari mulai Penyidikan termasuk dalam penyusunan berkas perkara dan tata cara perolehan alat bukti.

Asas KUHAP yang menganut diferensiasi fungsional merupakan pangkal masalah dari seringnya gesekan antara institusi penyidikan. KUHAP yang menganut asas diferensiasi fungsional, akan menimbulkan suatu pertanyaan bagimana posisi dari dominus litis dalam KUHAP jika dipadukan dengan integrared criminal justice system yang didalamnya terkandung asas diferensiasi fungsional. Maksudnya ialah apabila kita berangkat dari pemahaman bahwa dominus litis ialah pengendali perkara, maka sejauh mana tahapan proses pemeriksaan yang dapat dipandang sebagai dominis litis Kejaksaan R.I. Pertanyaan ini merupakan suatu konsekuensi atas fakta bahwa hubungan antara Kepolisian dengan Kejaksaan pada tahapan Penyidikan hanya sebatas koordinasi fungsional.

KUHAP yang menganut prinsip spesialisasi, deferensiasi dan kompertemensi, tidak hanya membedakan dan membagi tugas serta kewenangan,

\footnotetext{
${ }^{6}$ RM. Surachman, Mozaik Hukum I: 30 Bahasa Terpilih, Sumber Ilmu Jaya, Jakarta, 1996, hlm. 83.

${ }^{7}$ Kejaribone, Problematika Penerapan Prinsip Dominus Litis dalam Perspektif Kejaksaan, dikutip dari website: https://www.kejari-bone.go.id/artikel/detail/3/problematika-penerapan-prinsip-dominus-litis-dalam-perspektifkejaksaan.html

${ }^{8}$ Ibid
} 
tetapi juga memberi suatu sekat pertanggungjawaban lingkup tugas penyelidikan, penyidikan, penuntutan dan pemeriksaan di sidang pengadilan yang terintegerasi. Integrated justice system tersebut diartikan sebagai suatu proses pidana merupakan keterpaduan dari suatu subsistem penyidikan, sub sistem penuntutan sampai kepada sub sistem pemeriksaan dipersidangan dan berakhir pada sub sistem pelaksanaan putusan pengadilan. Akibat yang muncul dari prinsip diferensiasi fungsional, tergambar dari beberapa kasus yang berujung adanya putusan bebas dari Majelis Hakim, dikarenakan saksi atau terdakwa mencabut BAP dalam suatu perkara. Pencabutan BAP saksi atau terdakwa tersebut, dikarenakan tekanan atau rekayasa kasus pada tahap penyidikan yang dilakukan oleh pihak kepolisan selaku Penyidik. Kejadian di atas jelas merugikan Penuntut Umum serta terdakwa itu sendiri, dikarenakan bagi Penuntut Umum dengan saksi atau terdakwa mencabut BAPnya, maka secara langsung akan mengurangi kekuatan pembuktian dalam proses persidangan. Dengan lemahnya pembuktian oleh Penuntut Umum, maka akan menimbulkan banyaknya putusan bebas yang disebabkan hilangnya amunisi alat bukti yang dapat disajikan oleh Penuntut Umum.

Putusan bebas atas suatu perkara dapat menimbulkan suatu stigma negatif bahwa Penuntut Umum telah gagal dalam menangani suatu perkara. Di sisi Terdakwa, permasalahan ini menimbulkan suatu ketidakpastian hukum serta pula dapat mengindikasikan bahwa terdakwa dalam memberikan keterangan di penyidikan berada di bawah tekanan atau siksaaan. Artinya, permasalahan ini bukanlah sekedar pengandaian teoritis semata. Oleh karena itu, perlu dilakukan revisi hukum acara pidana dengan menerapkan prinsip dominus litis agar terjadi hubungan yang sinergi, khususnya antara Penyidik dan Penuntut Umum.

Goodwill Pemerintah dalam mereformasi hukum belum dapat dilihat serius karena sampai sekarang Revisi KUHAP sebagai dasar hubungan Penyidik dan Penuntut Umum masih jalan di tempat dan telah berlangsung puluhan tahun. Untuk mengantisipasi adanya celah-celah yang menjadi keluhan Penuntut Umum dalam menjalankan tugas dan wewenangnya, saat ini perlu adanya wacana penerapan prinsip dominus litis yang diberikan kepada Institusi Kejaksaan Republik Indonesia dalam proses penegakan hukum yang selanjutnya dapat diakomodir dalam pembahasan Revisi KUHAP, sebagai bagian dari upaya untuk memperkuat Jaksa selaku pengendali perkara pidana.

\section{Rumusan Masalah}

Rumusan permasalahan penelitian ini adalah bagaimana fungsionalisasi prinsip dominus litis dalam penegakan hukum pidana di Indonesia? 


\section{Tujuan Penelitian}

Penelitan ini bertujuan untuk mengetahui fungsionalisasi prinsip dominus litis dalam penegakan hukum pidana di Indonesia.

\section{Metode Penelitian}

Penelitian ini merupakan penelitian hukum normatif atau disebut juga penelitian hukum kepustakaan ${ }^{9}$ yang dilakukan dengan cara menelaah dan menginterpretasikan hal-hal yang bersifat teoritis yang menyangkut asas, konsepsi, doktrin dan norma hukum mengenai permasalahan yang diangkat. Penelitian ini menggunakan pendekatan perundang-undangan dan pendekatan konseptual. Data penelitian ini berupa bahan hukum primer, sekunder, dan tersier yang diperoleh melalui studi dokumen, studi kepustakaan, dan wawancara.

\section{Hasil Penelitian dan Pembahasan}

Sejak berlakunya KUHAP Tahun 1981, kejaksaan tidak lagi melakukan penyidikan terhadap tersangka tindak pidana umum yang diatur dalam KUHP. Ini berarti bahwa proses pemeriksaan terhadap tersangka dilakukan oleh penyidik tanpa campur tangan sama sekali dari penuntut umum. Satu-satunya ketentuan yang memungkinkan kejaksaan selaku penuntut umum bisa memonitor proses penyidikan yaitu apabila setelah dimulainya penyidikan, penyidik memberitahukan kepada penuntut umum melalui apa yang disebut dengan Surat Pemberitahuan Dimulainya Penyidikan (SPDP). Keadaan seperti diuraikan di atas, berbeda dengan di Amerika Serikat sebagaimana dikatakan oleh Andi Hamzah dan R.M. Surachman, bahwa dalam perkara-perkara yang berat sekali seperti pembunuhan, jaksa bisa memimpin penyelidikan sendiri atau bersama-sama dengan polisi mendatangi tempat kejadian perkara. ${ }^{10}$

Permasalahannya adalah antara penyidik dan penuntut umum sering kali memiliki ketidaksamaan pandangan terhadap suatu perkara pidana. Untuk perkara tindak pidana umum penuntut umum tidak diperkenankan campur tangan dalam proses penyidikan sehingga penyidik dan penuntut umum memiliki domain sendiri-sendiri. Artinya, terhadap suatu perkara pidana mungkin terjadi perbedaan persepsi antara penyidik dan penuntut umum atas tindak pidana yang dilakukan oleh tersangka. Ketidaksinkronan dalam interaksi penyidikan dan penuntutan ini dapat berakibat pada proses peradilan yang

${ }^{9}$ Soerjono Soekanto dan Sri Mamudji, Penelitian Hukum Normatif - Suatu Tinjanan Singkat, PT. Rajagrafindo Persada, Jakarta, 2010, hlm. 27

${ }_{10}$ R.M. Surachman dan Andi Hamzah, Jaksa di Berbagai Negara (Peranan dan Kedudukannya), Sinar Grafika, Jakarta, 1994, hlm. 5. 
berlarut-larut dan dapat merugikan hak tersangka karena proses peradilannya tidak segera dilakukan sesuai asas cepat, sederhana dan biaya ringan. Banyak tersangka kasus pidana harus menjalani masa tahanan maksimal karena proses pemberkasan perkara dan pengumpulan alat dan barang buktinya terhambat pada proses pra ajudikasi/penuntutan. ${ }^{11}$

Kendala atau hambatan hukum yang dihadapi oleh Penuntut Umum kaitannya dengan prinsip dominus litis dalam perkara tindak pidana umum, sebagaimana diterangkan oleh Chaeruman Harahap, yaitu jika ada beberapa hambatan penegakan supremasi hukum, maka dapat disebabkan faktor belum sempurnanya perangkat hukum, aparat penegak hukum belum memiliki integritas moral yang tinggi, aparat belum profesional, penghasilan aparat belum terjamin kesejahterannya, belum terwujud kesadaran hukum dalam masyarakat, belum maksimal sarana dan prasarana dan masih ada campur tangan dari eksekutif di dalam proses peradilan. ${ }^{12}$

Berdasarkan hasil wawancara penulis dengan Penyidik Kepolisian Resor Sleman diperoleh keterangan koordinasi yang dibangun antara Kejaksaan dalam hal ini Penuntut Umum dan Kepolisian dalam hal ini Penyidik sejauh ini sangat bagus hanya saja dalam beberapa hal ada suatu perkara yang memang membutuhkan tenaga ektra khususnya dalam hal mencari alat bukti sebagaimana yang menjadi petunjuk dari Penuntut Umum. Hal itu yang kemudian menghambat dalam proses penyidikan dan memakan waktu cukup lama karena menurut Penyidik petunjuk yang diberikan oleh Penuntut Umum tersebut menemui berbagai kendala dilapangan yang dalam hal ini Penuntut Umum tidak mengetahui secara langsung karena Penuntut Umum tidak terjun secara langsung atau turut serta dalam Penyidikan tersebut. Di sisi lain menyebabkan bolak baliknya suatu perkara. ${ }^{13}$

Pemaparan di atas menunjukkan tidak adanya keterpaduan antara Penyidik dan Penuntut Umum dalam penanganan suatu perkara ego dari masing-masing instansi membuat penanganan suatu perkara menjadi tersendat dan berlarut-larut sehingga menjadikan suatu perkara tersebut menggantung dan tidak ada titik penyelesaian. Hal ini tentunya akan merugikan seseorang yang telah ditetapkan menjadi tersangka dalam mendapatkan keadilan. Akibatnya, hal ini menjadi pekerjaan rumah bagi penegakan hukum di Indonesia khususnya dalam mencapai tujuan hukum terutama dalam hal mendapatkan keadilan.

11 Zainab Ompu Jainah, Pengaturan Interaksi Proses Penyidikan dan Penuntutan daalam Sistem Peradilan Pidana di Indonesia, Jurnal Ilmu Hukum KEADILAN PROGRESIF Program Studi Ilmu Hukum Fakultas Hukum Universitas Bandar Lampung Volume 9 Nomor 1 Maret 2018 hlm. 2.

12 Ari Yusuf Amir, Strategi Bisnis Jasa Advokat, Navila Idea, Yogyakarta, Maret, 2008, hlm. 19-20.

13 Wawancara dengan Penyidik Kepolisian Resor Sleman, pada 10 Juni 2021. 
Ketika penuntut umum berpendapat bahwa hasil dari penyidikan dapat dilakukan penuntutan maka penuntut umum dapat membuat surat dakwaannya. Selanjutnya, apabila penuntut umum memutuskan untuk menghentikan penuntutan karena tidak terdapat cukup bukti atau bukan tindak pidana atau bahkan karena ditutup demi hukum maka penuntut umum menuangkannya dalam bentuk ketetapan. Berdasarkan kewenangan yang dimiliki kejaksaan tersebut dapat disimpulkan bahwa penentuan dapat tidaknya suatu berkas perkara dilimpahkan ke pengadilan berada di tangan penuntut umum. ${ }^{14}$

Prinsip dominus litis terfungsionalisasi dalam pengaturan kewenangan untuk menghentikan penuntutan yang dimiliki oleh kejaksaan, sebagaimana diatur dalam Pasal 140 ayat (2) KUHAP. Pasal tersebut mengatur tiga komponen alasan yang menjadi dasar penghentian penuntutan, yaitu a) tidak terdapat cukup bukti; b) peristiwa tersebut bukan merupakan tindak pidana karena dilakukan oleh pelaku sakit jiwa (Pasal $44 \mathrm{KUHP}$ ), terpaksa (Pasal 48KUHP), pembelaan diri (Pasal 49 KUHP), pelaksanaan Undang-Undang (Pasal 50 KUHP) dan karena Perintah Jabatan yang sah (Pasal 51 KUHP), Tersangka/ Terdakwa meninggal dunia, Kadaluarsa kasus (Pasal 78 KUHP), terdapat alasan pembenar maupun pemaaf; c) Perkara Ditutup Demi Hukum, karena berlakunya asas ne bis in idem (Pasal $76 \mathrm{KUHP}$ ), adanya pembayaran denda tertinggi (Atdoening buitenprocess) (Pasal $82 \mathrm{KUHP}$ ), pengadu sudah mencabut aduan (Pasal 75 dan Pasal 284 ayat (4) KUHP) berdasarkan P-26. Penghentian penuntutan tersebut masih dapat diajukan pra peradilan (Pasal 80 KUHAP) dan masih dituntut kembali jika ditemukan Bukti Baru (novum). Selain itu, penghentian tersebut berimplikasi pada hilangnya tindak pidana dianggap tidak melakukan.

Penghentian penuntutan dapat dilakukan dengan alasan mengesampingkan perkara untuk kepentingan umum, sebagaimana diatur dalam Pasal 35C UndangUndang RI No. 16 Tahun 2004, tentang Kejaksaan Republik Indonesia. Kepentingan umum yang dimaksud adalah kepentingan bangsa dan negara dan atau kepentingan masyarakat luas. Jadi, tindak pidana tetap ada namun dikesampingkan. Ketentuan ini merupakan implementasi asas oportunitas yang hanya dapat dilakukan oleh Jaksa Agung dengan berpedoman pada asas kehatihatian dan masyarakat tidak dapat mengajukan pra peradilan namun dapat mengajukan judicial review kepada Ketua Mahkamah Agung atas pengesampingan perkara oleh Jaksa Agung. Jika pengenyampingan perkara sah maka tidak dapat dilakukan penuntutan lagi.

Hasil wawancara penulis dengan Jaksa Penuntut Umum Kejaksaan Negeri Sleman menyatakan, bahwa sejatinya koordinasi yang telah dibangun antara

\footnotetext{
${ }^{14}$ Adji, Indriyanto Seno, KUHAP dalam Prospektif, Diadit Media, Jakarta, 2011, hlm. 92.
} 
Penyidik dengan Penuntut Umum telah berlangsung cukup baik, namun demikian tidak sedikit perkara yang kemudian dikembalikan kepada Penyidik untuk dilengkapi karena berbagai kekurangan, dalam praktiknya untuk perkara yang tersangkanya tidak dilakukan penahanan sangat rawan disalahgunakan yang berakibat pada tidak ditindaklanjutinya suatu perkara yang mengaibatkan perkara tersebut kemudian tidak jelas penyelesaiannya dan bisa dikatakan menggantung. Namun demikian, banyak pula perkara yang kemudian dilanjutkan dan diputuskan oleh Penuntut Umum telah memenuhi rumusan tindak pidana dan dinyatakan lengkap, namun kendala yang dihadapi oleh Penuntut Umum adalah terkait dengan rasa keadilan bagi pelaku tindak pidana, contohnya dalam suatu perkara yang jelas Penuntut Umum memandang terkait dengan rumusannya sudah dirasa lengkap namun ternyata dalam tingkat penyidikan antara pihak korban dengan tersangka telah berdamai dan telah ada penggantian biaya atas kerugian yang dialami. Untuk menjembatani hal tersebut ada hal yang baru yang kemudian diperkenalkan oleh Institusi Kejaksaan yang disebut dengan Keadilan Restoratif. ${ }^{15}$

Keadilan restoratif merupakan salah satu upaya yang dapat dilakukan Kejaksaan dalam memfungsionalisasikan prinsip Dominus Litis. Merujuk Peraturan Jaksa Agung Nomor 15 Tahun 2020, definisi keadilan restoratif yaitu penyelesaian perkara tindak pidana dengan melibatkan pelaku, korban, keluarga pelaku/ korban dan pihak lain yang terkait untuk bersama-sama mencari penyelesaian yang adil dengan menekankan pemulihan kembali pada keadaan semula dan bukan pembalasan. Penghentian penuntutan berdasarkan keadilan restoratif dilaksanakan dengan asas keadilan, kepentingan umum, proporsionalitas, pidana sebagai jalan terakhir dan mengedepankan asas cepat, sederhana dan biaya ringan.

Pendekatan keadilan restoratif dalam penyelesaian perkara tindak pidana khususnya tindak pidana umum dilakukan oleh Kejaksaan berdasarkan Peraturan Jaksa Agung Nonor 15 Tahun 2020 tentang Penuntutan Berdasarkan Keadilan Restoratif. Selama 2020 Kejaksaan telah menghentikan penuntutan sebanyak 222 perkara dengan berdasarkan prinsip keadilan restoratif. ${ }^{16}$ Proses penegakan hukum melalui pendekatan keadilan restoratif selalu memperhatikan aspek transparansi dan akuntabilitas.

Penyelesaian perkara di luar pengadilan dengan pendekatan keadilan restoratif inilah salah satu hal yang bisa menghentikan penuntutan. Penghentian penuntutan berdasarkan keadilan restoratif dilakukan oleh Penuntut Umum secara bertanggung

${ }^{15}$ Wawancara dengan Jaksa Penuntut Umum Kejaksaan Negeri Sleman, pada 11 Juni 2021

16 Jaksa Agung ST. Burhanuddin "Kejaksaan Hentikan 222 Perkara lewat Keadilan Restoratif", https://www.hukumonline.com/berita/baca/lt601056e7ece43/kejaksaan-hentikan-222-perkara-lewat-keadilanrestoratif/, diakses 21 Juni 2021 
jawab dengan tetap mempedomani Peraturan Jaksa Agung Nomor 15 Tahun 2020 sebagai payung hukumnya. Untuk menghentikan penuntutan berdasarkan keadilan restoratif, jaksa perlu mempertimbangkan sejumlah hal. Misalnya, subjek, objek, kategori, dan ancaman tindak pidana, latar belakang terjadinya tindak pidana, tingkat ketercelaan, kerugian atau akibat yang ditimbulkan dari tindak pidana, cost and benefit penanganan perkara, pemulihan kembali pada keadaan semula, serta adanya perdamaian antara Korban dan Tersangka.

Ketentuan terkait syarat suatu perkara dapat ditutup demi hukum atau dihentikan penuntutannya berdasarkan keadilan restoratif adalah, pertama, tersangka baru pertama kali melakukan tindak pidana. Kedua, tindak pidana hanya diancam dengan pidana denda atau diancam dengan pidana penjara tidak lebih dari 5 tahun. Ketiga, tindak pidana dilakukan dengan nilai barang bukti atau nilai kerugian yang ditimbulkan akibat dari tindak pidana tidak lebih dari Rp. 2.500.000,00.

Pasal 5 ayat (8) Peraturan Jaksa Agung Nomor 15 Tahun 2020 mengatur bahwa penghentian penuntutan berdasarkan keadilan restoratif dikecualikan terhadap beberapa jenis tindak pidana, yaitu pertama, tindak pidana terhadap keamanan negara, martabat Presiden dan Wakil Presiden, negara sahabat, kepala negara sahabat serta wakilnya, ketertiban umum, dan kesusilaan. Kedua, tindak pidana yang diancam dengan ancaman pidana minimal. Ketiga, tindak pidana narkotika. Keempat, tindak pidana lingkungan hidup. Kelima, tindak pidana yang dilakukan oleh korporasi. Terkait hal ini, Pasal 6 Peraturan Jaksa Agung tersebut mengatur bahwa pemenuhan syarat penghentian penuntutan berdasarkan keadilan restoratif digunakan sebagai pertimbangan Penuntut Umum untuk menentukan dapat atau tidaknya berkas perkara dilimpahkan ke pengadilan.

Upaya mengfungsionalisasikan prinsip dominus litis dilihat dari perspektif keadilan restoratif yaitu proses mediasi yang diatur dalam Undang-Undang Nomor 11 Tahun 2012 tentang Sistem Peradilan Pidana Anak. Mediasi penal sebagai konsekuensi logis dari pendekatan restorative justice tersebut memiliki beberapa model yaitu, pertama, mediasi informal yang dapat dibantu oleh pekerja sosial atau pejabat pengawas (probation officer), oleh pejabat polisi, atau oleh Hakim. Kedua, peradilan adat (traditional village or tribal moot) yang lebih ke negara yang daerahnya masih pedesaan atau urban village. Ketiga, mediasi antara pelaku dan korban (victim-offender mediation) berlaku untuk semua pelaku tindak pidana, yaitu ada yang khusus untuk anak, untuk tipe tindak pidana tertentu, tipe pelaku pemula, dan tipe residivis.

Keempat, program negosiasi untuk melakukan perbaikan (reparation negotiation programme) yang mengutaamakan kompensasi atau perbaikan yang 
harus dibayar oleh pelaku kepada korban/ keluarga korban. Kelima, tokoh/peradilan komunitas (community panels or courts) yang mengutamakan unsur mediasi atau negosiasi. Keenam, musyawarah kekeluargaan atau komunitas (Family and community group conferences) yang melibatkan partisipasi masyarakat dan para pendukung korban.

\section{Penutup}

\section{Kesimpulan}

Berdasarkan hasil penelitian dan pembahasan di atas dapat disimpulkan bahwa prinsip dominus litis terfungsionalisasi dalam pengaturan kewenangan untuk menghentikan penuntutan yang dimiliki oleh kejaksaan, sebagaimana diatur dalam Pasal 140 ayat (2) KUHAP. Pasal tersebut mengatur tiga komponen alasan yang menjadi dasar penghentian penuntutan, yaitu tidak terdapat cukup bukti, peristiwa tersebut bukan merupakan tindak pidana, perkara ditutup demi hukum. Penghentian penuntutan juga dapat dilakukan dengan alasan mengesampingkan perkara untuk kepentingan umum, sebagaimana diatur dalam Pasal 35C Undang-Undang RI No. 16 Tahun 2004 tentang Kejaksaan Republik Indonesia. Selain itu, keadilan restoratif merupakan salah satu upaya yang dapat dilakukan Kejaksaan dalam memfungsionalisasikan prinsip dominus litis, contohnya yaitu proses mediasi (mediasi penal) yang diatur dalam UndangUndang Nomor 11 Tahun 2012 tentang Sistem Peradilan Pidana Anak.

\section{Saran}

Berikut disajikan saran atau rekomendasi dari hasil penelitian ini sebagai berikut yaitu jika nantinya diakomodir dalam suatu peraturan diharapkan jaksa dapat hadir pada saat dilakukan penyidikan, dimana saat pemeriksaan berlangsung jaksa yang hadir secara langsung tersebut tidak boleh melakukan intervensi dalam proses tesebut. Intervensi dapat dilakukan dengan metode prapenuntutan sehingga setiap tindak pidana atau perbuatan dapat menjadi semakin jelas dan besar kemungkinan terhindari dari hal-hal yang nantinya dikhawatirkan akan mempengaruhi pembuktian dalam penuntutan. Hal yang paling utama adalah perlu kesatuan rasa antara Penyidik dan Penuntut umum sebagai susb sistem dari satu kesatuan Sistem Peradilan Pidana yang apabila salah satu kalah maka akan timbul ketimpangan hukum secara luas. Kedua instansi harus sama-sama membangun citra tanpa merendahkan satu sama lain. Karena baik buruknya hasil kerja adalah mutlak kinerja bersama. Dalam melaksanakan kerjasama penanganan perkara pidana penyidik dan penuntut umum selalu mengingat tujuan yang ingin dicapai selain kepastian hukum dan kemanfaatan yaitu keadilan. 


\section{Daftar Pustaka}

\section{Buku}

E. Conklin, Jhon, The Impact Of Crime, McMillan Publishing Co, New York, 1975.

Fajar ND, Mukti, Dualisme Penelitian Hukum Normatif \& Empiris, Pustaka Pelajar, Yogyakarta, 2013.

H. Winarta, Frans, Suara Rakyat Hukum Tertinggi, Kompas, Jakarta, 2009.

Kusumaatmadja, Mochtar, Konsep-Konsep Dalam Pembangunan, PT. Alumni, Bandung, 2006.

Seno Adji, Indriyanto, KUHAP dalam Prospektif, Diadit Media, Jakarta, 2011.

Soekanto, Soerjono dan Sri Mamudji, Penelitian Hukum Normatif - Suatu Tinjauan Singkat, PT. Rajagrafindo Persada, Jakarta, 2010.

Surachman, RM., Mozaik Hukum I: 30 Bahasa Terpilih, Sumber Ilmu Jaya, Jakarta, 1996.

dan Andi Hamzah, Jaksa di Berbagai Negara (Peranan dan Kedudukannya), Sinar Grafika, Jakarta, 1994.

Rahman Saleh, Abdul, Bukan Kampung Maling Bukan Desa Ustadz, Kompas Media Nusantara, Jakarta, 2008.

Widhayanti, Erni, Hak-Hak Tersangka/Terdakwa di dalam KUHAP, Liberty, Yogyakarta, 1996

Yusuf Amir, Ari, Strategi Bisnis Jasa Advokat, Navila Idea, Maret, Yogyakarta 2008.

\section{Jurnal atau Karya Ilmiah}

Marwan Effendy, Deskresi Dalam Penegakan Hukum Tindak Pidana Korupsi, Makalah disampaikan pada Seminar Nasional yang diselenggarakan oleh Universitas Brawijaya Malang, Malang, 11 Juni 2012.

Zainab Ompu Jainah, Pengaturan Interaksi Proses Penyidikan dan Penuntutan dalam Sistem Peradilan Pidana di Indonesia, Jurnal Ilmu Hukum KEADILAN PROGRESIF Program Studi Ilmu Hukum Fakultas Hukum Universitas Bandar Lampung Volume 9 Nomor 1 Maret 2018.

\section{Website}

Jaksa Agung ST. Burhanuddin "Kejaksaan Hentikan 222 Perkara lewat Keadilan Restoratif", https://www.hukumonline.com/berita/baca/lt601056e7ece43/kejaksaa n-hentikan-222-perkara-lewat-keadilan-restoratif/, diakses 21 Juni 2021

Kejaribone, Problematika Penerapan Prinsip Dominus Litis dalam Perspektif Kejaksaan, https://www.kejari-bone.go.id/artikel/detail/3/problematikapenerapan-prinsip-dominus-litis-dalam-perspektif-kejaksaan.html 